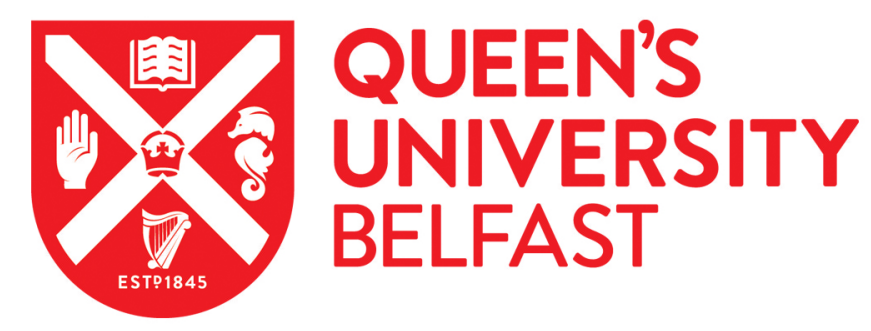

\title{
Drivers and challenges to water tariff reform in Saudi Arabia
}

Mcllwaine, S., \& Ouda, O. (2020). Drivers and challenges to water tariff reform in Saudi Arabia. International Journal of Water Resources Development, 36(6), 1014. https://doi.org/10.1080/07900627.2020.1720621

\section{Published in:}

International Journal of Water Resources Development

\section{Document Version:}

Peer reviewed version

Queen's University Belfast - Research Portal:

Link to publication record in Queen's University Belfast Research Portal

\section{Publisher rights}

(C) 2020 Taylor \& Francis. This work is made available online in accordance with the publisher's policies. Please refer to any applicable terms of use of the publisher.

\section{General rights}

Copyright for the publications made accessible via the Queen's University Belfast Research Portal is retained by the author(s) and / or other copyright owners and it is a condition of accessing these publications that users recognise and abide by the legal requirements associated with these rights.

Take down policy

The Research Portal is Queen's institutional repository that provides access to Queen's research output. Every effort has been made to ensure that content in the Research Portal does not infringe any person's rights, or applicable UK laws. If you discover content in the Research Portal that you believe breaches copyright or violates any law, please contact openaccess@qub.ac.uk. 


\title{
Drivers and Challenges to Water Tariff Reform in Saudi Arabia
}

\author{
Stephen J McIlwaine', Omar K M Ouda ${ }^{2}$ \\ 1 School of the Natural and Built Environment, Queen's University Belfast, UK. \\ Orcid ID: 0000-0001-5245-6737
} ${ }^{2}$ National Centre for Water Research and Studies, Ministry of Environment, Water and Agriculture, Riyadh,
Kingdom of Saudi Arabia. Orcid ID: 0000-0002-2556-756X

Corresponding author: Stephen McIlwaine (s.mcilwaine@qub.ac.uk), School of the Natural and Built Environment, Queen's University, Belfast BT7 1NN, United Kingdom.

\section{Publication details}

International Journal of Water Resources Development, 24 Feb 2020.

DOI: $10.1080 / 07900627.2020 .1720621$

\begin{abstract}
In 2015, increases in the domestic water tariff in Saudi Arabia were met with significant opposition. Although the increases were needed to address the technical and financial sustainability of the service in the context of extreme scarcity and high costs, insufficient effort was made to explain the changes and prepare the public. This paper examines the trade-offs surrounding the design of a domestic water tariff, based on economic theory and global experience, and sets out the competing factors Saudi Arabia should consider when designing a new tariff structure to provide long term public acceptability while ensuring the service remains sustainable.
\end{abstract}

Keywords: domestic water tariff, water economics, public views, Saudi Arabia.

\section{Introduction}

Meeting the demand for potable water is a major challenge to policy makers in Saudi Arabia. The country's renewable water resources are extremely limited, yet the country needs to meet the demands of a growing population and a developing economy. Historically, low water tariffs have led to high and rising domestic demand, with the bulk of the supply provided by costly desalinated seawater (59\%) and non-renewable groundwater (35\%) (Ministry of Environment, Water and Agriculture [MEWA], 2017a). In 2015, the revenue generated by the domestic water tariff contributed only around $7 \%$ of the estimated marginal cost of the domestic supply (Ouda, 2013a). This is unsustainable both environmentally and economically.

The problem came into focus with the fall in oil prices in 2014-2015, which led to a significant deficit in the government's fiscal budget, and pressure to remove subsidies and bring in more revenue from the provision of public services. In December 2015, the Ministry of Finance announced reductions in the subsidies for domestic water supply, gasoline and electricity (National Water Company, 2016). For the water sector, this meant a sharp increase in the domestic water tariff, and for most households, the monthly water bill rose at least 10-fold (Zetland, 2017). This was met with significant and unprecedented public criticism (New Arab, 2016). The minister of water and electricity and the chief executive officer of the National Water Company were replaced (Freyberg, 2016), and the new minister then announced that a new, more acceptable water tariff would be developed (Bloomberg, 2016; Reuters, 2016). Although the new tariff has been retained in the meantime, steps were initiated to develop a new tariff structure; but to date, it has not been announced.

Both the magnitude of the price increase and the resulting opposition were unique. The government needs to introduce a tariff which moves towards higher cost recovery and lower water demand, but which is acceptable to the public, and it must do this in a nation undergoing significant social and political reforms.

This paper discusses the Saudi experience in adjusting the domestic water tariff. It draws on economic theory and global experience to underline the need for pricing reform, while emphasizing the need to address the public's willingness and ability to pay for water at higher rates. It explains how a new tariff structure must ultimately address the need to recover costs, reduce water demand and incentivize utility performance, but 
also be publicly acceptable in the developing socio-political context. It stresses that engagement of the public is essential to establishing their acceptance of the new tariff.

\section{Considerations from the literature on establishing a price for water}

Determining the price of water is a complex challenge which involves considering the cost of supply; consumer demands, attitudes, and willingness and ability to pay; and public policy on how much of the cost of the service is recovered, and how cost recovery is distributed across a varied customer base. The cost of supply is affected by climate, geography, topography, the storage and supply infrastructure, and policy decisions on the type of service provided. Consumer attitudes are influenced by culture, experience, assumptions, political context, and perceptions of reliability and quality. Particular factors which Saudi Arabia should take into account are discussed below.

For domestic water supply, the classical economic approach of allowing the market to set the price of water is problematic. Water is considered a special economic good which should not be priced simply at the intersection of supply and demand (Maxwell, 2010). Water is an essential, non-substitutable good and is too bulky to be easily traded over large distances, factors not applicable to other goods (Van der Zaag \& Savenije, 2006). The high costs of production and transportation are barriers to entry to new producers, which often leaves large monopolies running domestic water services. Water therefore tends to be treated differently from other commodities, and is often handled by the government rather than free markets. This is reflected in the pricing of water, where instead of allowing the market to set the price, artificial pricing structures are created which aim to recover costs while ensuring access to safe water for all, supposedly taking ecological requirements into account (Van der Zaag \& Savenije, 2006). Where markets are used to price water, this is typically in conditions of a supply-demand imbalance, where pricing needs to signal the need to conserve, as in the Murray-Darling and Middle Rio Grande basins (Maxwell, 2010).

Equity issues arise in relation to both access and affordability. The equity principle requires that charges for essential services should be provided affordably to all regardless of ability to pay. Affordability is typically measured by examining cost as a proportion of income, using macro indicators such as national net income or national disposable income. The OECD (2003) recommends that households do not pay more than 3-5\% of household income, and the World Bank has the same requirement for post-loan water charges in lower-income countries. A refinement of this approach uses the price of only the amount of water needed to cover basic needs, rather than the actual amount paid (García-Valiñas, Martínez-Espiñeira, \& González-Gómez, 2010). The US Environmental Protection Agency guidance is for households to spend no more than 2\%ofmedian household income on water services and $4.5 \%$ on water and wastewater services (Mack \& Wrase, 2017).

Equity considerations also require that the cost/income test be applied regionally and across income groups, rather than nationally or using coarse average income figures. Even in OECD countries where affordability is not an issue on a national scale, regional variations in income or poverty can give rise to pockets of affordability problems. A 2003 review of affordability in 18 OECD countries found cost-to-income ratios varying from $0.5 \%$ in the US to $2.4 \%$ in Poland, but the ratio was significantly higher for the lowest income group. The ratio for England and Wales increased from $1.2 \%$ at a national level to $3.75 \%$ for the lowest income group, and in Netherlands from 1.4\% to 2.38\% (OECD, 2003). Amore recent study of 60 cities in 43 countries also found that the proportion of household income paid for the water and wastewater service ranged from $0.5 \%$ to $2.5 \%$ in the cities considered, again with significant variation due to differences in income (Wichelns, 2013). In Cebu, the Philippines, poor households pay $7.3 \%$ of their total income for water services, compared with only $1.8 \%$ for high income households in the same city (Chun, 2014). One study suggests that $60 \%$ of the population in lowincome countries would struggle to afford water services priced for full cost recovery (Mack \& Wrase, 2017). Saudi Arabia is not in OECD, nor is it regarded as a low income country, but its large range of household incomes means that both factors are relevant.

Several measures are used to address affordability (Wichelns, 2013). Income-support measures target the customer rather than the price. These can include discounts, payment plans or loan facilities, and do not detract from the price-signalling of the value of water. They can be applied by government bodies with responsibilities for welfare rather than the water utility. Alternatively, tariff-related measures such as caps, subsidies and special tariffs, are applied to designated groups. These typically need to be organized by the water utility, so where the water utility is run as a public or private company, its responsibility for addressing affordability needs to be clearly set out in its articles of establishment. All OECD countries which have identified affordability problems for lower income households have introduced measures to address this (OECD, 2003). 
There is much discussion in the literature on the effect of water price on demand (e.g. Wang, Xie, \& Honglin, 2008). In standard economic theory, the price of a good relates inversely to its demand, expressed as price elasticity of demand (PED). For industrial and agricultural water uses, PED follows economic theory and is elastic. For domestic consumers, the PED curve for domestic water is an arc with three regions (Hoffman \& du Plessis, 2013). At moderate levels of consumption, the demand is elastic, and consumption decreases with increasing price, as the consumer is able to adjust usage. But the more consumption falls, the harder it is to reduce usage further, because a minimum amount of water is essential to survive. Here, demand becomes less affected by price, until at very low levels of consumption, PED tends towards zero. At this point, continued tariff rises have little effect on demand (Savenije \& van der Saag, 2002). Similarly, at higher values of consumption, a domestic household can only usefully use a certain amount of water, so there comes a point at which price reductions no longer increase demand. This all confirms that household water cannot be regarded simply as a marketable good, with price controls coarsely applied to address demand. Rather, an understanding of PED and household characteristics - composition, income level, garden size, standards of living, and household behaviour - must inform the design of the tariff system. For example, Oman's water is significantly subsidized, and removal of subsidies would raise the price from an average of USD 1.83/m3 to USD 5.4/m3. However, PED is known to be high, as many households use significant water for non-essential uses such as garden irrigation and car washing. Households here could reduce usage in response to a higher price (Kotagama, Zekri, Al Harthi, \& Boughanmi, 2017), which is important information when considering price rises.

Acceptability is typically discussed in relation to willingness to pay, or WTP (Massarutto, 2006). The price of water should be set below theWTP level for the consumer groups involved. In Saudi Arabia, the public opposition to the December 2015 price rises indicates that the new tariffs exceeded WTP. Measures are therefore needed to increase the willingness of the public to pay the new prices. Experience shows that where there is no underlying affordability problem, but the price is not acceptable, price rises should be gradual (OECD, 2003). Such situations require transitional policies to move consumers towards accepting higher prices for a commodity they have historically not valued. The new prices need to be explained and justified. Lessons may be learned from experiences with public engagement in other countries. In China, there is a requirement to engage the public on water prices, although so far, the procedure does not fully allow the general public to raise concerns and influence policy (Shen $\& \mathrm{Wu}, 2017$ ). Jordan - a neighbouring nation with a similar climate and scarcity of resources - ran a multi-year public campaign on water use, with a wide range of messages to different target groups. This addressed topics such as household appliances, reuse of ablution water in mosques, and landscape irrigation. An analysis of this campaign suggests that it led to some improvement in people's understanding of their responsibility for addressing water scarcity, but only marginally changed their water conservation behaviour (Zietlow, Michalscheck, \& Weltin, 2016). Although this campaign did not address price increases, the analysis illustrates the need for a well-designed, long-term engagement campaign running in parallel with tariff and non-tariff measures.

A key purpose of the tariff is to provide revenue to cover the cost of providing the service. Ideally, this should provide for the full financial and functional autonomy of the water institutions responsible (Olivier, 2010); Van der Zaag and Savenije, 2006). The tariff should also be economically efficient, and should ideally signal the full economic cost of supply, taking into account the cost to the environment and resource scarcity (OECD, 2003). A properly established price would incentivize allocation of water between sectors for maximum economic return. A study of global water price trends made the unsurprising observation that where water demand exceeds the available resource, the price of water rises to reflect the application of market forces and the need to allocate water to the highest-value uses (Maxwell, 2010). Market forces will increasingly drive a more efficient allocation of resources, especially in areas of supply/demand imbalance. The Murray-Darling basin in Australia and parts of the western United States are two areas which have an increasing supply deficit, and these are also where the most advanced water trading markets are developing, and where the price of supply is steadily rising. As water scarcity grows, the emergence of market trading mechanisms is inevitable, to allow the scarce resource to be allocated more efficiently. This will see polic ymoving beyond 'water development' into a new era of 'water allocation' (Maxwell, 2010). Thus, within increasing pressure on the public purse and with very limited renewable resources, Saudi Arabia will be not be able to avoid a trajectory towards higher prices for water over the long term. Also, a study published in 2012 of tariffs in 308 cities in both developed and less developed countries, found that while higher prices are often needed in situations of scarcity to cover the cost of the more expensive sources, areas with higher prices tend to have better governance (Zetland \& Gasson, 2012).

Benchmarking water prices against other countries is also useful. A 2013 study of tariffs in 60 cities in 43 countries found that the average rate for domestic water ranged from less than USD $1 / \mathrm{m} 3$ in Asia and Africa to more than USD 3.5/m3 in Europe, North America and Australia, with 51 cities having a rate higher than USD 4/m3 (Wichelns, 2013). The global average unit rate was USD 2.1/m3; 81 cities had a rate below USD 0.5/m3, and Saudi Arabia's rates put it into this bracket. 
A commonly applied tool which combines cost recovery objectives with equity considerations is the increasing block tariff, or IBT (Boland \& Whittington, 2000; OECD, 2003; Olivier, 2010, and others). An IBT divides consumption into blocks, with higher blocks having a higher unit price. This provides a minimum amount of affordable water to all households, while signalling and incentivizing the importance of conservation at higher consumption levels. IBTs are designed to address the objectives of affordability, fairness, resource conservation and economic efficiency (Olivier, 2010) and also effectively introduce a cross-subsidy from high usage consumers to low-usage consumers. Also, if the higher block tariff corresponds to the marginal rate, a degree of economic efficiency is satisfied at the higher consumption levels. IBTs are common in developing countries, as well as in some OECD countries - Japan, Spain and many areas of the US (Olivier, 2010) - and as illustrated below, are a feature of both the pre-2015 and post-2015 water tariffs in Saudi Arabia.

IBTs are often criticized, as they mean that all consumers benefit from some subsidized water, which is not economically efficient (Dalhuisen et al., 2003); also, since the block sizes are usually set independently of household size, large families are penalized (Boland \& Whittington, 2000). In Spain, where large households are common (as they are in Saudi Arabia), utilities have addressed this through a range of special tariffs for larger households, which modify the IBT rates and reduce the cost per person of basic water needs for large households (Arbués Arbués \& Barberán, 2012). Economists also complain that an IBT is regressive, with the highest-value water attracting the lowest price, while lower-value uses such as garden irrigation attract the highest price (Hoffman \& du Plessis, 2013). This is clearly illustrated by the ineffectively designed IBT applied in Manaus, Brazil, where most consumers use only the highly subsidized lower-consumption blocks. The low tariffs failed to incentivize resource conservation, and the wide nature of the lowest block meant that poor households were unable to reduce their bill through lower use (Olivier, 2010). This illustrates that to design an effective IBT tariff structure, information needs to be available on consumers' awareness of the tariff structure, and their willingness to change usage across the blocks (Nuages \& Whittington, 2009).

When designing an IBT, therefore, the variation in consumer behaviour and PED needs taken into account. In South-East Asia, a wide variety of tariffs are applied, but price mechanisms such as the IBT are the most common means of managing urban water demand, although the relative price inelasticity has limited their effect (Wichelns, 2013). Non-price mechanisms such as public education and rationing are commonly used in combination with an IBT, as well as technical measures such as pressure-reducing valves, constant flow meters and double-flush cisterns, and it seems that despite the variations in how water management practices are applied, a range of balanced measures is most effective, with the actual mix of tools depending on the local context (Wichelns, 2013). The Portuguese authorities recently published new guidelines on tariff setting for utilities which promote cost recovery, sustainable use of resources, affordability and transparency.

These favour an IBT approach where the blocks are set locally across the country, using knowledge of actual household needs and behaviour (Pinto \& Marques, 2015). Four blocks are recommended, varying from 0-5 m3 to over $25 \mathrm{~m}$ s per month, on top of a monthly fixed charge of $€ 1.5$ for a typical connection. The rate of rise is set locally, and there may be adjustments for both seasonal and low incomes.

Saudi Arabia's water sector is currently unsustainable

Water resources

Renewable water sources in Saudi Arabia are extremely limited (Chowdhury \& Al-Zahrani, 2015). Surface water collected in wadis across the country is captured in 503 dams, which have a total storage capacity of 2.4 billion cubic metres (BCM), or just 10\% of total annual consumption (MEWA, 2017a). The dams are mostly in Assir, Makkah and Jizan Provinces, in the south and west. Their total exploitable reserve currently amounts to about 1.6 BCM/y (MEWA, 2017a); they provide flood control, groundwater recharge, and water supply for irrigation and domestic uses in the dam catchment areas. Renewable groundwater is found in a range of shallow and deep aquifers of the Arabian Shield region in the western regions of the country. According to the latest available published figures, these two sources together provide an estimated $6.2 \mathrm{BCM} / \mathrm{y}$ of potential resource (MEWA, 2017a).

Saudi Arabia supplements these renewable sources with desalinated seawater, particularly to meet potable and industrial demand. Desalinated seawater is produced at 35 desalination plants, which have a total installed capacity of $2292 \mathrm{MCM} / \mathrm{y}$ (2015 figures), planned to grow to $2701 \mathrm{MCM} / \mathrm{year}$ by 2020 (MEWA, 2017a). Desalinated seawater is costly to produce - an average production cost of USD $0.8 / \mathrm{m}_{3}$, in addition to the cost of pumping and transportation from the coast to inland demand centres - and also has a high environmental cost, 
not least from the brine waste produced, which raises the ambient marine water temperature and harms coral reef communities. The country is also increasing its use of treated sewage effluent for non-potable uses such as industrial processes, cooling, irrigation and landscaping (Chowdhury \& Al-Zahrani, 2015). In 2015, 0.61 MCM of treated sewage effluent was produced per day, with $65 \%$ of this going to agriculture (MEWA, 2017a). There is potential to increase the use of treated sewage effluent, as current usage represents only around $17 \%$ of the nation's potential treated sewage effluent resource. Other nations in the region use much more: Abu Dhabi uses $40 \%$, Sharjah 63\%, Cyprus 85\%, and Dubai $90 \%$ of its available treated sewage effluent (MEWA, 2017a).

Even with these supplies, the total water demand is not met, and the government has been drawing down nonrenewable groundwater reserves in more than 20 aquifers across the kingdom. These reserves are estimated at 2360 BCM, but they are not evenly distributed around the country: more than two thirds of the exploitable nonrenewable groundwater is in the Eastern Region, Riyadh, Hail and Al Jawf Provinces (MEWA, 2017a). This abstraction has costs. Abstraction beyond the sustainable yield draws down water levels and increases pumping costs. The Saudi National Water Strategy reported that the aquifers in Qassim Province will be depleted by 2030, and those in Riyadh by 2048, if the present abstraction rates and consumption trends continue (MEWA, 2017a). The overexploitation of aquifers beyond their sustainable yields also degrades groundwater quality, with increasing salinity and radioactivity being found in areas where over-abstraction is highest (MEWA, 2017a).

Some demand management measures have been introduced, including introduction of the original water tariff in 1994, leakage reduction measures, the use of treated sewage effluent, and saline groundwater for irrigation and non-potable uses (Zaharani, Al-Shayaa, \& Baid, 2011). There is potential to co-opt more marginal resources: greywater (domestic wastewater, excluding toilet water), rainwater harvesting in micro-catchments, and treated oilfield brine could also contribute. But these uses all need further study and, while demand remains high, will only ever have a limited contribution to the overall resource mix. From the figures available (MEWA, 2017a), the urban water supply is made up from 35\% non-renewable groundwater, $3 \%$ renewable groundwater, $59 \%$ desalinated water and 3\% surface water. However, these figures take no account of the likely effects of climate change, with expected higher temperatures and lower rainfall intensity and humidity, which will reduce the available resources even further, leading to higher evapotranspiration, higher water demand and lower groundwater recharge (Sowers, Vengosh, \& Weinthal, 2011; DeNicola, Aburizaiza, Siddique, Khwaja, \& Carpenter, 2015; Chowdhury \& Al-Zahrani, 2015).

\section{Water demand}

Against this background, water demand in Saudi Arabia continues to rise sharply. Total demand has been rising at around 7\% per year since 2011, and reached 24.6 BCM in 2015 (MEWA, 2017a). About 84\% of this demand comes from agriculture, and $12 \%$ is domestic demand, with industry contributing about 4\% (MEWA, 2017a). There are clear opportunities to reduce allocation to the agricultural sector, but even focusing on the domestic sector, potable water requirements have been rising at around 6\% per year since 2011, and in 2015 reached 8.3MCM per day (MEWA, 2017a). Despite higher estimates being cited by various parties from time to time, the Saudi National Water Strategy reports that the average per capita usage in 2015 is estimated at 263 litres per capita per day (LCD), varying from 104 and 108 LCD in Asir and Najran Provinces, to 337 and 364 LCD in Riyadh and the Eastern Province (MEWA, 2017a). This is high for such a water-scarce country; compare with the much lower figures even in countries with much more abundant resources, such as Algeria (221 LCD), Greece (208 LCD), Oman (141 LCD) and Morocco (135 LCD). The reasons for such high demand may include high network losses, but are mainly attributable to the low price of water. The National Water Strategy's target is to reduce the national average to 200 LCD by 2020 (MEWA, 2017a).

The service is also financially unsustainable, due to the low level of costs recovered, which is due in part to the low price of water. Before the 2015 reforms (described below), the domestic water tariff followed an IBT which resulted in a weighted average revenue per unit of water of USD $0.08 / \mathrm{m}_{3}$. Since the latest cost estimates are that the average cost of water production, transportation and distribution is around USD $2 / \mathrm{m}_{3}$ in current figures (Ouda et al., 2017; World Bank, 2005), the revenue generated is likely to have contributed only around 7\% of the cost of water at pre-2015 prices (Ouda, 2013a). This meant that very little of the cost of the service was recovered from consumers. This was financially unsustainable and put tremendous pressure on the country's budget. Just as crucially, the under-priced water encouraged careless habits and high consumption among the population. Figure 1 benchmarks the national price of domestic water in Saudi Arabia (where the water price is the same in all cities) against the price in a number of worldwide cities ranked by GDP per capita, for the first $10 \mathrm{~m}_{3}$ of monthly consumption per household. The price of water in Saudi Arabia in 2015 is seen to be the lowest of all selected cases of reasonably comparable GDP per capita. The comparison is stark, illustrating the 
extent to which Saudi Arabia is an outlier in domestic water pricing. Furthermore, the comparison calls for further analysis to assess the effect of the 2015 water price rise under higher levels of consumption.

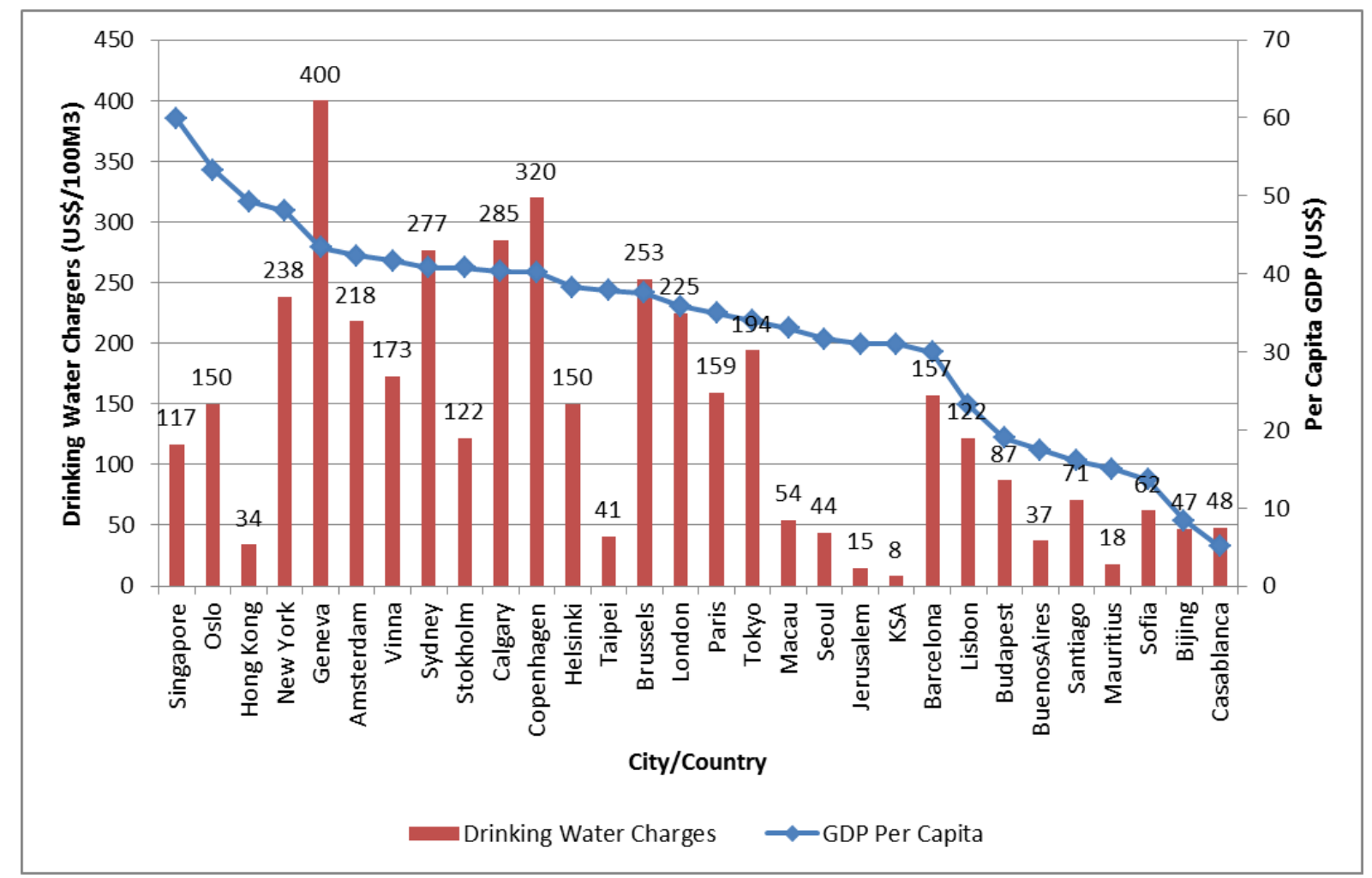

Figure 1. Comparison between water tariff and per capita GDP.

Source: Adapted from Hartley, Tortajada, and Biswas (2018), with data from International Water Association (2016).

The social and political context of tariff reform

As the world's leading oil producer, Saudi Arabia's economy is heavily reliant on the oil sector, which accounts for $45 \%$ of GDP, $90 \%$ of total exports, and $80 \%$ of government income (Jawadi \& Ftiti, 2019). Oil revenue has historically been used to subsidize public services to a significant extent (Atalla, Gasim, \& Hunt, 2018) and (Ouda, 2013a). The sharp fall in oil prices in 2014/2015 had a significant impact on the Saudi economy, with the Saudi stock market having lost $10 \%$ of its value by mid-2014, and the public deficit rising to $16 \%$ in 2015 (Jawadi \& Ftiti, 2019). The government was forced to look to reductions in expenditures and seek new sources of income, and a reduction in subsidies to public services - water, electricity and gasoline - was announced. The water tariff rise of December 2015 should be understood against this background.

In 1994, for the first time, a moderate water tariff was introduced, water having been free until then. The tariff was based on a five-block IBT applied uniformly to metered connections across the country (Table 1).

Table 1. Pre 2015 Block Tariff Rates.

\begin{tabular}{|l|l|l|}
\hline Block & $\begin{array}{l}\text { Monthly consumption } \\
\left(\mathbf{m}^{\mathbf{3}}\right)\end{array}$ & $\begin{array}{l}\text { Price } \\
\left(\mathbf{U S D} / \mathbf{m}^{\mathbf{3}}\right)\end{array}$ \\
\hline 1 & $1-50$ & 0.027 \\
\hline 2 & $51-100$ & 0.04 \\
\hline 3 & $101-200$ & 0.53 \\
\hline 4 & $201-300$ & 1.07 \\
\hline 5 & $301+$ & 1.6 \\
\hline
\end{tabular}

Source: National Water Company, (NWC, 2017).

In December 2015, in response to the call to gradually remove subsidies, the Saudi cabinet issued Decision No. 95 (National Water Company, 2016), which announced a revised tariff structure, applicable to all domestic customers (Table 2). This structure remains in force to date. 


\begin{tabular}{|l|l|l|l|l|l|}
\hline Block & $\begin{array}{l}\text { Monthly } \\
\text { Consumption } \\
\left(\mathbf{m}^{\mathbf{3}}\right)\end{array}$ & $\begin{array}{l}\text { Water } \\
\text { Price } \\
\left(\mathbf{U S D} / \mathbf{m}^{\mathbf{3}}\right)\end{array}$ & $\begin{array}{l}\text { Wastewater } \\
\text { Price } \\
\left(\mathbf{U S D} / \mathbf{m}^{\mathbf{3}}\right)\end{array}$ & $\begin{array}{l}\text { Total Water and } \\
\text { Wastewater Price } \\
\left(\mathbf{U S D} / \mathbf{m}^{\mathbf{3}}\right)\end{array}$ & $\begin{array}{l}\text { Meter Maintenance monthly } \\
\text { fees (USD according to } \\
\text { incoming pipe diameter } \\
(\mathbf{m m}))\end{array}$ \\
\hline 1 & Less than 15 & 0.027 & 0.013 & 0.04 & $(0-20 \mathrm{~mm}) 1.33$ \\
\hline 2 & $16-30$ & 0.27 & 0.13 & 0.4 & $(25-40 \mathrm{~mm}) 2.67$ \\
\hline 3 & $31-45$ & 0.8 & 0.4 & 1.2 & - \\
\hline 4 & $46-60$ & 1.067 & 0.533 & 1.6 & - \\
\hline 5 & $60+$ & 1.6 & 0.8 & 4.8 & $\mathrm{~mm}) 4.0$ \\
\hline
\end{tabular}

Source: National Water Company, (NWC, 2017).

Although the revised structure retains five blocks, the block widths have been reduced significantly. The highest block is now reached after $60 \mathrm{~m}_{3}$ of consumption per month, compared to $300 \mathrm{~m}_{3}$ previously. Usage of $61 \mathrm{~m} 3$ per month now attracts a marginal rate of USD $4.8 / \mathrm{m}_{3}$, from the previous USD $0.04 / \mathrm{m}_{3}$. Fees have been included for the first time to cover wastewater management costs, and these follow an IBT approach to the water tariff. The monthly price for $50 \mathrm{~m}_{3}$ of water supplied (excluding wastewater and meter fees) has risen 16-fold from USD 1.35 to USD 21.79, while for $100 \mathrm{~m} 3$ of water supplied, it has risen almost 29-fold, from USD 3.35 to USD 96.46. The combined monthly bill for water, wastewater and metering fees has become USD 35.27 for $50 \mathrm{~m} 3$ of usage, an almost 26-fold increase over the pre-2015 bill for the same amount of water, while for $100 \mathrm{~m}_{3}$, it is USD 244.60, a 72-fold increase. The new tariff was calculated to increase cost recovery to around $30 \%$ of the estimated marginal cost of water (Government of Saudi Arabia [GOSA] 2016b; Ouda, 2013a), and as such was only the first step towards meeting the Saudi Vision 2030 goal of full cost recovery.

When the price rises were introduced in 2015 , there was significant unease, leading to public criticism of the government on social media. Although there is no formal report or analysis of this, people shared photographs of their new bills on line, and publicly expressed astonishment at the size of the price rises, even allowing themselves to be quoted in public (New Arab, 2016). The new prices were felt to be unfair, and the Consumer Protection Association asked the government to rethink them (Bloomberg, 2016). The strength of opposition was surprising in a country where open criticism of the government is unusual, and illustrates what many commentators are pointing out about the changing nature of Saudi society. For much of the Arab world, the events of the Arab Spring in 2010-2012 highlighted a lack of public participation in decision making. In Saudi Arabia, although this did not manifest as public opposition to the government, it did lead to demands for more public participation in decision making (Alshaikh, 2019). The public's voice has been strengthened by the growth of social media, which created unprecedented opportunities for the sharing of information (Thompson, 2018), and also encouraged greater political awareness. The combination of demographic changes towards a younger society, more education, and expanding availability of new media and social media has increased political awareness among the youth and contributed to what some call this 'rapid societal transformation' within Saudi society (Thompson, 2017). The virtual sphere has also provided opportunity for the public to gather and discuss and share ideas more easily. One result of this has been a raising of expectations of government services, and demands for more effective dialogue with the government on policy issues (Kanie, 2012). This youth reformist trend remains 'still loyal to the Government, but demands an opening of the political system to include a wide social base' (Al Rasheed, qtd. in Thompson, 2017). Saudi society has always had well-established means of harnessing public debate and producing a consensus, e.g. via majalis, diwaniyyat and istirihat (different types of social gatherings), but this is now increasingly mediated via social media (Thompson, 2017).

The public reaction to the water tariff rise illustrated the lack of preparation of public perception, particularly in the light of these societal changes, and was a signal to the water authorities that changes are needed in the way such a change is determined and communicated. The reaction was compounded by the historic low price of water, which meant that most domestic consumers had not been aware of the true costs of supply, and had not needed to control consumption or even be aware of consumption levels. The government immediately understood the political sensitivity of the situation, and the minister of water and electricity and the chief executive officer of the National Water Company were replaced, together with an announcement that a new publicly acceptable tariff would be developed (Bloomberg, 2016; Reuters, 2016; Freyberg, 2016). These measures partially cooled the wave of criticism, and while the new tariff system has been maintained to date, implementation of the planned rise towards meeting the goal of 100\% cost recovery (cited in Saudi Vision 2030) was suspended pending further study of the situation. As reported by Global Water Intelligence (2017), the International Monetary Fund subsequently confirmed its view that the new tariff levels were widely 
unpopular, and that a more gradual implementation would have been preferable, giving households more time to adapt. Another effect of the higher prices is that households have typically become more aware of their water bills, which has highlighted problems with the accuracy of the water metering system. Years of low water tariffs had demotivated both consumers and the water utilities from maintaining and operating the water supply system efficiently, including billing and metering. Customers had not been motivated to maintain their residential plumbing systems to prevent leaks, as the cost of wasted water was so low. With the higher prices, the cost of wasted water was suddenly more apparent. The National Water Company quickly recognized this and has initiated a countrywide programme to replace mechanical meters with 'smart meters' incorporating automated meter-reading technology. Two million smart meters were planned to be installed across the country by the end of 2019 (National Water Company, 2019).

Several lessons can be drawn from Saudi Arabia's experience in adjusting the water tariff. First, even in this middle-income country, where ability to pay is not a problem for most households, a sudden increase in the water tariff provoked substantial public resistance, which has hindered the tariff development plan towards full cost recovery. The lack of information on WTP before the tariff adjustments, and the lack of public engagement to explain the changes, meant that the adjustment was implemented too suddenly, without the assurance of public acceptance. This highlights the value of conducting a comprehensive study to understand WTP, and engagement to prepare the public. The new tariff was applied across the country without any consideration of variations in water availability, water production and distribution cost, ability to pay and affordability, or the economic conditions of the different regions in the country. An economically efficient water tariff should take careful account of this variability and make appropriate regional adjustments, carefully explained, to ensure public support.

The new tariff has exposed technical weaknesses in water metering and billing. The more consumers are asked to pay, the higher their expectations of the service. Water meter accuracy was known to be suboptimal before the tariff rise, but the price hike exposed the unreliability of the readings (or at least strengthened the public's perception of the meters' inaccuracy), which further reduced the public's acceptance of the new tariff. This highlights the importance of ensuring the technical readiness and capability of the metering network and billing systems before implementing price rises.

Before 2018, the National Water Company was managing water and wastewater services in The main five cities (Riyadh, Jeddah, Makah, Madinah and Taif), while the Ministry of Water and Electricity was responsible for water and wastewater services in the rest of the country, as well as acting as the regulator. It is generally accepted that when the same institution acts as both service provider and regulator, less efficient service results, given the conflict of interest inherent in the competing mandates. Following the response to raising the tariff, the government realized that a clearer division of mandates was needed, and in 2017 the Electricity and

Cogeneration Regulatory Authority was appointed as the regulator for water services, in addition to its mandate as regulator for electricity services. This is a reflection of the authority's history of successfully managing the electricity tariff, and will put a greater distance between regulation and operations in the water sector.

Related to this, the legal framework and institutional capacity of the water sector institutions need to be capable of providing an efficient and functioning water tariff system. The suboptimal institutional and legal framework and weak human capacity before 2015 had limited the public sector's capacity to tackle the tariff adjustment and was a key reason for the substantial public resistance. This is now being addressed by bringing in international and local expertise to support the ministry in various planning ventures. Finally, it has become apparent that an aggressive water tariff adjustment towards full cost recovery needs to be implemented gradually over an extended period of time, and with protections for lower-income households. When water bills suddenly increase more than 10-fold, public opposition is to be expected. Therefore, raising the price of water needs to be done gradually and coupled with a comprehensive public preparation and awareness programme over an extended period.

\section{A sustainable way forward}

Public sector reform, the National Water Strategy and plans to restructure the tariff In April 2016, the government announced a new strategic vision and comprehensive roadmap for economic development in the Kingdom, Saudi Vision 2030 (GOSA, 2016a), which recognizes the need to reform public-sector operations and finances and move public services onto a more sustainable footing. The National Transformation Program 2020 was then published and is being implemented to help realize this vision. It sets targets for public agencies, which include reducing domestic consumption from 256 to $200 \mathrm{LCD}$, and increasing the percentage of the water supply costs recovered via the tariff from $30 \%$ to $100 \%$ in 2020 (GOSA, 2016b). As part of this strategic 
reform, in 2017 the government published a wide-ranging National Water Strategy (MEWA, 2017a). This addresses legal, institutional and regulatory issues, as well as issues of allocation and pricing. One of its initiatives was to establish a new tariff structure for water and wastewater service. When the government then moved responsibility for tariff reform to the Electricity and Co-Generation Regulatory Authority, it tasked the authority with designing a tariff structure which would achieve partial cost recovery and signal the value of water so as to control the demand, while remaining acceptable to the public. The new tariff structure is mandated to address five criteria: economic efficiency, cost recovery, affordability, equity, and simplicity and ease of implementation (MEWA, 2017a). The National Water Strategy calls for a progressive increase in tariffs, aimed at achieving cost recovery and signalling to consumers the full cost of delivering the service, as well as subsidies targeted at low-income households where affordability is likely to be a problem. The authority therefore has the challenging task of adjusting the domestic tariff to meet these competing objectives. The tariff must be sufficiently high to raise enough revenue to pay for the service and signal the importance of conserving water, while being affordable and acceptable to a public unused to paying anything close to the real cost of the service. The new structure will need to include a trajectory of tariff rises which will gradually reduce the subsidy until the gap between costs and revenue disappears and full cost recovery is achieved. The challenge will be to achieve this as fast as is publicly acceptable.

Addressing public acceptability and willingness to pay

For most consumers in Saudi Arabia, affordability is not in question. Using public data from the General Authority of Statistics (www.stats.gov.sa), the Ministry of Environment, Water and Agriculture's calculations suggest that even with the 2015 price rises, the ratio of average bill per household to national average household income is $0.13 \%$, well below the threshold of affordability (MEWA, 2017b). For most of the population, therefore, it is public acceptability and WTP which needs to be addressed, rather than affordability. Although the precise levels of WTP are not known, from the 2015-16 opposition it can be assumed that the 2015 rises were initially above WTP at that time. Further study is needed to identify the real, effective values of ability to pay and WTP in the various regions in the country. Given the government's stated objective of reaching full cost recovery, and that the 2015 reforms have only pushed cost recovery to $30 \%$ of the total costs (Government of Saudi Arabia, 2016b). it is clear that tariffs still have far to rise, and that WTP must continue to be pushed up over time. Yet there are low income households where affordability could become a problem, and more study is needed of the effects of the higher water tariff, and possible means to address this.

Much can be learned from the experiences of other similarly water-stressed environments. A progressive and gradual schedule for tariff raising can be designed with the input of consumers and stakeholders, even including feedback on the block steps (assuming an IBT continues to be used), the number of blocks, and unit price of each. Presentation of accurate cost data will reinforce the message of cost recovery, and should include operation and maintenance, depreciation, maintenance, and future capital needs. Benchmarking of the tariffs to those in neighbouring countries may be helpful in justifying the price levels, and it may be helpful to introduce differential regional tariffs to reflect regional income levels and differential service costs. Contingent valuation studies based on different tariff structure scenarios may also help identify WTP for different consumer demographics.

\section{Public consultation and engagement}

A programme of public education and awareness raising will help raise levels of WTP, even if this is a gradual process. Such a programme should emphasize the cost of providing good-quality, reliable service, the need for the utility to recover at least part of its costs from consumers, and the current gap between costs and revenue. It should introduce information on the scarcity of the resource in Saudi Arabia and the high levels of domestic consumption, as well as the value of water in such a water-stressed environment. Messages should clarify the degree to which domestic water consumption can be reduced with little impact on quality of life. The inclusion of the wastewater service fee must also be explained. Crucially, an effective communications campaign should also include specific advice on tools and strategies to reduce water consumption in the household and commercial contexts, including practical steps to address leakage in the household, curtail unnecessary use in the kitchen, shower and laundry, limit landscape irrigation, and so on. These messages may initially be unwelcome to a population unused to conservation, and to whom the value of water has not been clearly emphasized, and so a gradual, progressive, multi-message approach will be necessary, with regular review and adjustment. In parallel with price rises and a public communications programme, a subsidy programme for lowincome households should be designed and clearly explained, emphasizing the principle of support for the vulnerable and needy. As time goes on, more advanced messages could include discussion of the trade-offs between efficiency and equity, and the need to limit unsustainable and unaffordable consumption. 
During the preparation of this manuscript, in March 2019, MEWA announced a wide spectrum water conservation awareness programme, QATRA (National Water Company, 2019), designed to encourage the preservation of water as a non-renewable national resource in line with Saudi Vision 2030. The programme has yet to be implemented, and its effects must be examined after an appropriate period. However, it is a welcome first step and suggests that the ministry appreciates the need to raise public awareness regarding water conservation. It should be complemented by well-planned and progressively implemented comprehensive water awareness programmes designed to meet the stated goals of a sustainable water sector and raise the public's WTP for water services.

\section{Conclusion}

Given the historic high levels of subsidy of public services in Saudi Arabia, and the low price of water, domestic water consumption is higher than it needs to be. The stark imbalance between demand and the renewable resources available to meet that demand, as well as the government's desire to increase the overall sustainability of the Saudi economy and reign in the government budget, mean that the government must increase the cost of water to the consumer. Higher prices will be more economically efficient and will support fuller recovery of the cost of the service. However, as the opposition to price rises in 2015 have demonstrated, despite their only increasing cost recovery to around $30 \%$, and being well below the affordability threshold for most consumers, WTP for domestic water supply is limited, so any restructuring of the tariff therefore needs to be implemented gradually.

International experience, and these first attempts by Saudi Arabia to increase the water tariff, show that water tariff adjustment needs to be based on a comprehensive long-term plan, which includes several elements. First, a nationally coordinated, comprehensive communication and public awareness programme targeted at raising WTP in the general population needs to be designed and implemented in parallel with any tariff reforms. This should have clarity and transparency at its core. Information about the water sector status in the kingdom - the limited resources, the balance of supply and demand, the financial and environmental costs of desalination and non-renewable groundwater abstraction - should be carefully delivered. The impact of high subsidies on longterm public performance should be highlighted. Messages should be included on who should bear the burden of rising costs, and emphasize the protection of lower-income households. As part of this, the long-term tariff strategy must be presented and explained to the public with clear objectives, in cooperation with community groups and industry stakeholders, so that all parties can plan to absorb and cope with the changes gradually, over time.

Second, there needs to be a gradual adjustment of the water tariff. Gradual implementation will allow residents to absorb and accept the increase. The rate of adjustment should be planned based on a comprehensive study of the public's WTP and ability to pay, and on predictions of the dynamic response of WTP to the education programme over time.

Third, affordability needs to be addressed. Even in Saudi Arabia, there are low-income households where affordability is a problem. The tariff rises need to be mitigated by suitable adjustments for low-income households to ensure affordability to all, based on appropriately applied metrics, which take into account variations in household income and size, and even regional variations. Care should be taken to protect lowerincome demographic groups from price increases, whether by income-support measures applied by the relevant government agencies, or by tariff-related measures applied by the water utility. It is important that these are based on accurate information on household income and affordability.

Fourth, as part of the settlement, the management and operational performance of the public utilities must be improved, both the supply service and the metering and billing. The public trust gained through more robust and accurate metering and careful billing will reduce the reluctance of customers to pay for the service, and reduced losses due to missing data and inaccurate or disputed bills will increase the cost recovery ratio.

Fifth, a stronger institutional and legal framework needs to be developed, supported by a multidisciplinary human-capacity-building programme within the water utility and the ministry, to ensure effective implementation of a water tariff adjustment system. The kingdom needs to develop a water-sector road map to set out the reform and capacity building improvements needed.

Finally, political realism is needed. Water tariff reforms can be contentious. Understanding institutional inertia and potential resistance to change is important. Depoliticizing water pricing by basing it on justifiable and 
transparent technical and financial needs, rather than arbitrary considerations, will improve the chance of success.

\section{Acknowledgments}

The key messages of this paper were presented at a Water Economics Workshop held in Riyadh on 12 December 2019 under the auspices of the Ministry of Environment, Water and Agriculture, and involving the World Bank, OECD and Global Water Intelligence.

\section{Data availability statement}

The data for Figure 1 can be accessed via http://reshare.ukdataservice.ac.uk/853740/. The data described in this article are openly available in the Open Science Framework at doi:10.17605/OSF. IO/TPA6U.

\section{Disclosure statement}

No potential conflict of interest was reported by the authors.

\section{ORCID}

Stephen J. McIlwaine http://orcid.org/0000-0001-5245-6737

Omar K. M. Ouda http://orcid.org/0000-0002-2556-756X

\section{References}

Alshaikh, A. B. (2019). Citizen participation in Saudi Arabia: A study of the Ministry of Labour. Asian Affairs, 50(1), 112-123. doi:10.1080/03068374.2019.1567105

Arbués Arbués, F., \& Barberán, R. (2012). Tariffs for urban water services in Spain: Household size and equity. International Journal of Water Resources Development, 28(1), 123-140. doi:10.1080/07900627.2012.642235

Atalla, T. N., Gasim, A. A., \& Hunt, L. C. (2018). Gasoline demand, pricing policy and social welfare in Saudi Arabia: A quantitative analysis. Energy Policy, 114, 123-133. doi:10.1016/j.enpol.2017.11.047

Bloomberg. (2016, May 17). New environment minister Abdulrahman Al Fadli draws up new tariff following complaints over high bills. Arabian Business. Retrieved from https://www.arabianbusiness.com/new-saudiminister-set-affordable-water-tariff-631981.html

Boland, J. J., \& Whittington, D. (2000). Water tariff design in developing countries: Disadvantages of increasing block tariffs (IBTs) and advantages of uniform price with rebate (UPR) designs. IDRC Research Paper, 2000. Retrieved from http://efdinitiative.org/publications/water-tariff-designdeveloping-countries-disadvantages-increasing-block-tariffs-and

Chowdhury, S., \& Al-Zahrani, M. (2015). Characterizing water resources and trends of sector wise water consumptions in Saudi Arabia. Journal of King Saudi University: Engineering Sciences, 27, 68-82. doi:10.1016/j.jksues.2013.02.002

Chun, N. (2014). Increasing access to water services: A cost-recoverable pricing model. International Journal of Water Resources Development, 30(4), 662-679. doi:10.1080/07900627.2014.895926

Dalhuisen, J. M., Rodenberg, C. A., De Groot, H. F., \& Nijkamp, P. (2003). Sustainable water management policy: Lessons from Amsterdam. European Planning Studies, 11(3), 263-281. doi:10.1080/09654310303636

DeNicola, E., Aburizaiza, O. S., Siddique, A, Khwaja, H, \& Carpenter, D. O. (2015). Climate change and water scarcity: The case of Saudi Arabia. Annals of Global Health, 81(3), 342. doi:10.1016/j.aogh.2015.08.005

Freyberg, T. (2016, May 1). Tariff Sheikh Up in Saudi. Water and Wastewater International. Retrieved from https://www.waterworld.com/articles/wwi/print/volume-31/issue-3/regulars/editor-s-note/tariff-sheikh-up-in-saudi.html

García-Valiñas, M., Martínez-Espiñeira, R., \& González-Gómez, F. (2010). Measuring water affordability: A proposal for urban centres in developed countries. International Journal of Water Resources Development, 26(3), 441458.doi:10.1080/07900627.2010.491971

Global Water Intelligence. (2017). IMF urges restraint on Saudi water tariff reform. Retrieved from https://www.globalwaterintel.com/news/2017/41/imf-urges-restraint-on-saudi-water-tariffreform Government of Saudi Arabia. (2016a). Vision 2030. Retrieved from www.vision2030.gov.sa/en 
Hartley, K., Tortajada, C., \& Biswas, A. K. (2018). Political dynamics and water supply in Hong Kong. Environmental Development, 27, 107-117. doi:10.1016/j.envdev.2018.06.003

Hoffman, J. J., \& du Plessis, J. A. (2013). Technical note: A model to assess water tariffs as part of water demand management. Water SA, 39(3). Retrieved from https://www.ajol.info/index.php/wsa/ article/view/90132

International Water Association. (2016). Total charges for 170 cities in 2015 for a consumption of $100 \mathrm{~m} 3$. International Statistics for Water Services. Retrieved from http://www.iwa-network.org/waterstatistics/ Jawadi, F., \& Ftiti, Z. (2019). Oil price collapse and challenges to economic transformation of Saudi Arabia: A time-series analysis. Energy Economics, 80(2019), 12-19. doi:10.1016/j.eneco.2018.12.003

Kanie, M. (2012). Civil society, language and the authoritarian context: The case of Saudi Arabia. Orient, 53(iv), 44-54.

Kotagama, H., Zekri, S., Al Harthi, R., \& Boughanmi, H. (2017). Demand function estimate for residential water in Oman. International Journal of Water Resources Development, 33(6), 907-916. doi:10.1080/07900627.2016.1238342

Mack, E. A., \& Wrase, S. (2017). A burgeoning crisis? A nationwide assessment of the geography of water affordability in the United States. PLoS One, 12(1). doi:10.1371/journal.pone.0169488

Massarutto, A. (2006). Water pricing and full cost recovery of water services: Economic incentive or instrument of public finance? Water Policy, 9(6), 591-613. doi:10.2166/wp.2007.024

Maxwell, S. (2010, April). Historical water price trends. Journal of the American Water Works Association, 102, 24-28. doi:10.1002/j.1551-8833.2010.tb10086.x

Ministry of Environment, Water and Agriculture. (2017a). Saudi National Water Strategy 2030. Retrieved from https://www.mewa.gov.sa/ar/Ministry/Agencies/TheWaterAgency/Topics/Pages/Strategy.aspx

Ministry of Environment, Water and Agriculture. (2017b). Internal report presentation, Saudi national water strategy, water sector economics, NWS 2030 steering \& technical committees. Riyadh, Saudi Arabia.

National Water Company. (2016). Guide to water services. Retrieved from

https://www.nwc.com.sa/Arabic/Documents/\%D8\%AE\%D8\%AF\%D9\%85\%D8\%A7\%D8\%AA\%20\%D8\%A7\%D9\%84\% D8\%B9\%D9\%85\%D9\%84\%D8\%A7\%D8\%A1\%20\%D8\%A8\%D8\%B4\%D8\%B1\%D9\%83\%D8\%A9\%20\%D8\%A7\%D9\% 84\%D9\%85\%D9\%8A\%D8\%A7\%D9\%87\%20\%D8\%A7\%D9\%84\%D9\%88\%D8\%B7\%D9\%86\%D9\%8A\%D8\%A9\%20178-2016.pdf\#search=\%D8\%A7\%D9\%84\%D8\%BA\%D8\%B1\%D8\%A7\%D9\%85\%D8\%A7\%D8\%AA

National Water Company. (2017). Water tariffs - previous and new. Retrieved from https://www.nwc.com.sa/Arabic/Pages/NewTarrifCalculator.aspx (in Arabic).

National Water Company. (2019). Retrieved from https://www.nwc.com.sa/English/OurCompany/MediaCenter/NewsandEvents/News/Pages/WDS-installs-878,000-smartmeters-as-part-of-NTP-2020-digital-transformation-initiative.aspx

New Arab. (2016, March 24). Saudis boiling over exorbitant new water tariffs. Retrieved from https://www.alaraby.co.uk/english/society/2016/3/24/saudis-boiling-over-exorbitant-new-water-tariffs

Nuages, C., \& Whittington, D. (2009). Estimation of water demand in developing countries: An overview. World Bank Research Observer, 25(2), 263-294.

OECD. (2003). Social issues in the provision and pricing of water servicesRetrieved from https://www.oecdilibrary.org/environment/social-issues-in-the-provision-and-pricing-of-water-services 9789264099890 -en

Olivier, A. (2010). Water tariffs and consumption drop: An evaluation of households' response to awater tariff increase in Manaus, Brazil. Water Policy, 12(2010), 564-588. doi:10.2166/wp.2010.045

Ouda, O. K. M. (2013a). Review of Saudi Arabia municipal water tariff. Journal of World Environment, 3(2), 66-70.

Ouda, O. K. M., Khalid, Y., Ajbar, A. H., Rehan, M., Shahzad, K., Wazeer, I., \& Nizami, A. S. (2017). Longterm desalinated water demand and investment requirements: A case study of Riyadh. Journal of Water Reuse and Desalination, 8(3), 432-446. doi:10.2166/wrd.2017.107

Pinto, F., \& Marques, R. C. (2015). Tariff recommendations: A panacea for the Portuguese water sector? Utilities Policy, 43 , 36-44. doi:10.1016/j.jup.2014.12.003 
Reuters. (2016, April 24). Saudi king replaces minister for water and electricity. Arabian Business. Retrieved from https://www.arabianbusiness.com/saudi-king-replaces-minister-for-water-electricity-629325.html

Savenije, H., \& van der Saag, P. (2002). Water as an economic good and demand management. Paradigms with pitfalls. Water International, 27(1), 98-104. doi:10.1080/02508060208686982

Shen, W., \& Wu, J. (2017). State of the art review: Water pricing reform in China. International Journal of Water Resources Development, 33(2), 198-232. doi:10.1080/07900627.2016.1171743

Sowers, J., Vengosh, A., \& Weinthal, E. (2011). Climate change, water resources, and the politics of adaptation in the Middle East and North Africa. Climatic Change, 104, 599-627. doi:10.1007/s10584-010-9835-4

Thompson, M. C. (2017). Societal transformation, public opinion and Saudi youth: Views from an academic elite. Middle Eastern Studies, 53(5), 834-857. doi:10.1080/00263206.2017.1304918

Thompson, M. C. (2018). Saudi Arabia: Civil society and natural resource management. In I. Overland (Ed.), Public Brainpower. Cham: Palgrave McMillan. doi:10.1007/978-3-319-60627-9_16

Van der Zaag, P., \& Savenije, H. H. G. (2006). Water as an economic good: The value of pricing and the failure of markets (Value of Water Research Report Series, No. 19). Delft: UNESCO-IHE Institute for Water Education.

Wang, H., Xie, J., \& Honglin, L. (2008, August). Domestic water pricing with household surveys: A study of acceptability and willingness to pay in Chongqing, China (Policy Research Working Paper 4690). Washington DC: Sustainable Rural and Urban Development Team, World Bank.

Wichelns, D. (2013). State of the art review: Designing urban water tariffs to recover costs and promote wise use. International Journal of Water Resources Development, 29(3), 472-491. doi:10.1080/07900627.2013.828255

World Bank. (2005, March 31). A water sector assessment report on countries of the cooperation council of the Arab states of the Gulf (Report No 32539). Washington DC: MNA.

Zaharani, K. H., Al-Shayaa, M. S., \& Baid, M. B. (2011). Water conservation in the Kingdom of Saudi Arabia for better environment: Implications for extension and education. Bulgarian Journal of Agricultural Science, 17(3), 389-395.

Zetland, D. (2017). Desalination and the commons: Tragedy or triumph? International Journal of Water Resources Development, 33(6), 890-906. doi:10.1080/07900627.2016.1235015

Zetland, D., \& Gasson, G. (2012). A global survey of urban water tariffs: Are they sustainable, efficient and fair? International Journal of Water Resources Development, 29(3), 327-342. doi:10.1080/07900627.2012.721672

Zietlow, K. J., Michalscheck, M., \& Weltin, M. (2016). Water conservation under scarcity conditions: Testing the long-run effectiveness of a water conservation awareness campaign in Jordan. International Journal of Water Resources Development, 32(6), 997-1009. doi:10.1080/07900627.2016.1159947 